\title{
Use of Anguilla anguilla for Biomonitoring Persistent Organic Pollutants (POPs) in Brackish and Riverine Waters in Central and Southern Italy
}

\author{
Roberta Bettinetti - Silvana Galassi - Silvia Quadroni • Pietro Volta • \\ Fabrizio Capoccioni • Eleonora Ciccotti • Giulio A. De Leo
}

Received: 1 March 2010 / Accepted: 28 July 2010

(C) Springer Science+Business Media B.V. 2010

\begin{abstract}
One of the aims of the Water Framework Directive 2000/60/CE is to assess the ecological status of water bodies in Europe in relation to priority contaminants, including some persistent organic pollutants (POPs). Recognizing the benefits of measuring hydrophobic compounds in biota tissues rather than in water, we used the European eel Anguilla anguilla in the present study as a bioindicator species for monitoring
\end{abstract}

R. Bettinetti $(\bowtie) \cdot S$. Quadroni

Department of Chemical and Environmental Sciences, University of Insubria,

Via Valleggio 11,

22100 Como, Italy

e-mail: roberta.bettinetti@uninsubria.it

S. Galassi · S. Quadroni

Department of Biology, University of Milan,

Via Celoria 26,

20133 Milan, Italy

P. Volta

CNR ISE,

Largo Tonolli 50,

28922 Verbania, Italy

F. Capoccioni $\cdot$ E. Ciccotti

Department of Biology, University Tor Vergata,

Via della Ricerca Scientifica 1,

00133 Rome, Italy

G. A. De Leo

Department of Environmental Sciences,

University of Parma,

Viale Usberti 11/A,

43100 Parma, Italy
POPs in freshwater/brackish environments. We present the results of a contamination analysis of eels carried out in three Italian sites representative of different pollution levels: the last part of Tevere River, which flows through a very urbanized and industrialized area, Caprolace Lake and Lesina Lagoon, inside two different protected national parks. A very high pollution variability was recorded within each group of eels, in particular for those caught at Caprolace Lake. Due to this high variability, inter-population comparisons were carried out only between eels collected in Tevere River and Lesina Lagoon. PCBs values in Lesina Lagoon were two orders of magnitude lower than those measured in Tevere River, while no significant differences were found for levels of DDT compounds. Our results confirm the suitability of the eel as an indicator of persistent bioaccumulative pollutants in brackish environments and rivers where it can be easily caught, but we are sceptical of its use in deep lakes where its capture might be problematic considering standard operation procedures for fish sampling.

Keywords Bioindicator species $\cdot$ Eel $\cdot$ DDTs $\cdot$ PCBs . Water Framework Directive

\section{Introduction}

A selection of priority substances that included persistent organic pollutants (POPs) such as chlorinated pesticides, dioxins and polychlorinated biphenyls 
(PCBs) was enclosed in the EU Water Framework Directive 2000/60/EC (WFD) to outline parameters defining the ecological status of water bodies. Although Environmental Quality Standards (EQSs) are determined only for the water phase by Directive 2008/105/ $\mathrm{EC}$, a daughter directive of the WFD, there are strong arguments in favour of measuring hydrophobic compounds in biota tissues rather than in water, as assessed by Article 3 of the same Directive. Firstly, methodological problems arise when very low concentrations have to be quantitatively determined in water. For example, the US-EPA fact sheets summarizing current information on fish advisories recommend criteria for water quality assessment that are particularly protective for human health, i.e. $0.17 \mathrm{ng} / \mathrm{L}$ for PCBs (EPA 1999) and $0.22 \mathrm{ng} / \mathrm{L}$ (EPA 2000) for DDTs for fish/shellfish consumption. Unfortunately, current routine analytical methods can hardly detect such low levels of contaminants. In addition, the concentration of these substances might vary significantly within the same water body, especially in lakes, depending on hydrological phenomena, algal growth/settling, depth, sediment type etc. (Dachs et al. 2000; Söderström et al. 2000). Therefore, the collection of a single sample of water in a specific portion of a lake might be not representative of the bioavailable concentration of a pollutant over the entire water body. Furthermore, sediment resuspension and local inputs in rivers might temporarily influence the concentration of pollutants in the dissolved phase. As a consequence, the results of analyses performed on single water samples are often unsuitable for the assessment of the exposure of aquatic organisms to dissolved pollutants because of the horizontal and vertical patchiness of aquatic ecosystems and their variability over time (Bettinetti et al. 2010).

Biomonitoring using mussels and/or fishes can usually overcome the typical drawbacks of the analytical assessment of water quality for those lipophilic contaminants whose concentration in the water column is usually below the analytical detection limit (Barron et al. 1996). Moreover, biomonitoring can provide information to assess the threats posed by water contamination to aquatic communities both by direct evaluation of alterations occurring in polluted organisms (Koponen et al. 2001) and by an indirect evaluation of the risk posed to top predators through the use of theoretical calculations based on ecological models.
For instance, the zebra mussel Dreissena polymorpha, native to the Caspian and Black Seas and subsequently established in the UK, Western Europe, Scandinavia and many Mediterranean countries, has been used for the active and passive monitoring of bioaccumulable pollutants (de Kock and Bowmer 1993). However, contamination in zebra mussel should be considered representative only of the littoral benthic environment, which can be very different from the pelagic environment, particularly in deep lakes. Fish can also be used as biomonitors, even though some problems might arise when using a single fish species as bioindicator. As a matter of fact, this approach can pose a challenging problem since about half of the European species are present only in restricted geographical areas and the majority of these endemisms occurs in barrier regions with a Mediterranean climate (Griffiths 2006).

Quite recently, the European eel (Anguilla anguilla) has been proposed by Belpaire and Goemans (2007) as the ideal candidate for biomonitoring the chemical status of European water bodies according to WFD for the following reasons: (1) it is pervasively widespread in most European fresh and marsh waters and thus it potentially allows comparative analyses of the water quality in different environments; (2) it is sedentary, very fat and accumulates many lipophilic substances to a great extent, allowing the possibility of acquiring a significant bio-concentration of otherwise undetectable contaminants; (3) there is no reproduction and associated lipid metabolism in European waters, as eels are assumed to reproduce only after a long migration to the spawning area in the Sargasso sea. Moreover, monitoring contaminants in this species is also a public health issue as eel is an edible species and its farming currently supplies approximately 45,000 tons/year, which is more than the $80 \%$ of the world's consumption of the species (Nielsen and Prouzet 2008). Additionally, bioaccumulative pollutants may represent a risk factor for the conservation of the European eel, as contamination by POPs might have contributed significantly to the collapse of the European stocks (Buet et al. 2006; van Ginneken et al. 2009).

The aim of the present study was twofold. Firstly, we used eel specimens as bioindicators to define the chlorinated pesticide and PCBs contamination of a riverine environment (Tevere River) and of two brackish coastal lakes (Lesina Lagoon and Caprolace Lake), sites which are expected to present different 
degrees of contamination. Secondly, on the basis of the results, we discussed potential limitations of the use of the eel as a bioindicator in relation to the different ecosystems.

\section{Materials and Methods}

\subsection{Study areas and Collection of Eels}

Eel samples were collected in three sites (Fig. 1), different in typology (one river, two coastal lagoons) and in the expected level of contamination.

One site is the low course of the Tevere River, downstream of the town of Rome $\left(41^{\circ} 45^{\prime} \mathrm{N}\right.$ and $12^{\circ}$ $\left.17^{\prime} \mathrm{E}\right)$. The Tevere River is the longest river in Central Italy, rising in the Appenine Mountains and flowing $405 \mathrm{~km}$ to the Tyrrhenian Sea, draining a basin of about $18,000 \mathrm{~km}^{2}$. Its final stretch is approximately long $5.3 \mathrm{~km}$ and is barred by the Castel Giubileo Dam, that concentrates eel colonizing the river in this stretch. In this area, water quality is affected mainly by the inputs from a tributary, the river Aniene and by agriculture and municipal effluents rather than by industrial activities.

The two coastal lagoons are the Caprolace lake (Latium) and the Lesina Lagoon (Apulia).

The Caprolace Lake $\left(41^{\circ} 21^{\prime} \mathrm{N}\right.$ and $\left.12^{\circ} 58^{\prime} \mathrm{E}\right)$ has an area of $2.3 \mathrm{~km}^{2}$ and a maximum depth of $2.9 \mathrm{~m}$, and is connected to the sea by a tidal channel. The lagoon is part of a complex of four lakes that are the remnants of a land reclamation carried out in the 1930s. The lakes and the surrounding area are included in the Circeo National Park on the Italian coast of the Tyrrhenian Sea, and the site has been acknowledged since 1995 as a Ramsar Site. Water quality is at present relatively good, since in the early 1980s freshwater inputs were cut off due to the high level of nutrients flowing in the lagoon from the surrounding area, where intensive agriculture as well as cattle farming is present. As consequence, lagoon salinity increased and, at present, it ranges between

Fig. 1 Map of Italy and details of the three sampling sites

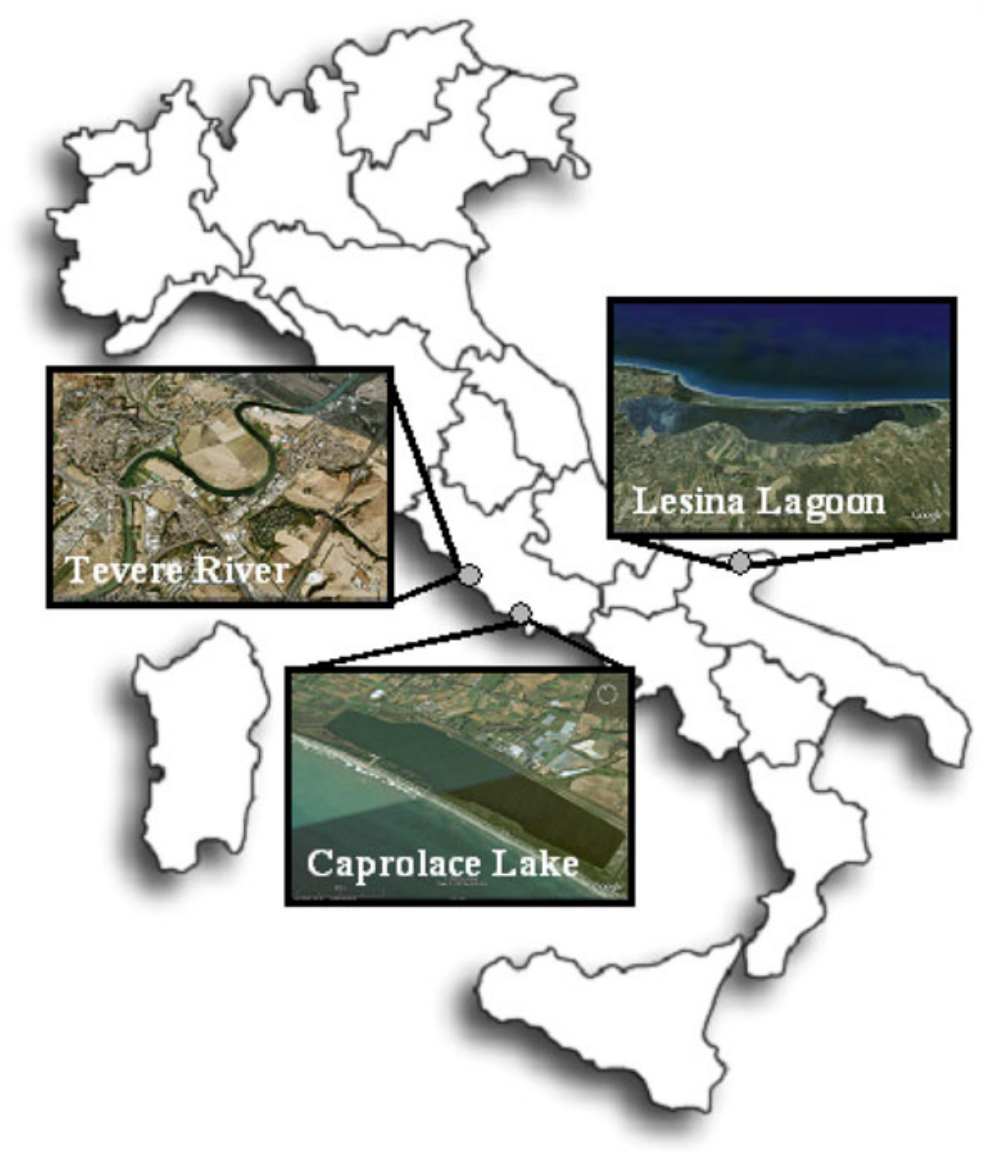


$34.8 \%$ and $42.9 \%$, with an average annual value of $38 \%$.

The Lesina Lagoon is situated on the Adriatic coast of Central-Southern Italy $\left(15^{\circ} 45^{\prime} \mathrm{E}, 41^{\circ} 88^{\prime} \mathrm{N}\right)$. This lagoon is included in the Gargano National Park and it has been acknowledged in 1995 as a Site of Community Importance. Its area amounts to $51.4 \mathrm{~km}^{2}$ and has a maximum depth of $1.5 \mathrm{~m}$, and is connected to the sea by two tidal channels, long 3 and $0.8 \mathrm{~km}$, respectively. The lagoon has a number of freshwater inputs, i.e. two main tributaries, many agricultural drainage channels and two drainage pumping stations. The catchment basin, about $460 \mathrm{~km}^{2}$ includes some livestock farms as well as seed and irrigated crops. Several fish farms discharge their waters, after treatment, into the western and central-eastern side of the lagoon, on the southern shore. Moreover, the partially treated urban waste waters of three municipalities, with a cumulated population amounting to 30000 inhabitants, flow into the lagoon.

Eels were collected, in all the three sites, by fyke netting (mesh size $10 \mathrm{~mm}$ ) in autumn/winter 20072008. A total of 40 eels were sampled: 22 eels were caught in Caprolace Lagoon, ten in the Lesina Lagoon, and eight were caught in the low course of the Tevere River.

All fishes were measured for total length and weight and examined to assign developmental stage on the basis of livery (yellow eel or silver eel). Each individual was anaesthetized with 2-phenoxyethanol $1 \%$ and then killed in order to collect otoliths for age evaluation, gonads for sex determination and muscle tissue for the analyses of POPs. Otoliths were extracted from all individuals, embedded in epoxyn resin, and stained with 3\% toluidine blue following grinding of the convex side (grinding and polishing method, ICES 2009). Individual age was determined by counting annual otolith rings (annuli) using a light stereomicroscope. Conventionally (ICES 2009), age for eel is evaluated by counting from the first ring after the central core of the otolith that accounts for the marine larval and post larval period of the eel. Assigned age corresponds, therefore, to the years of the animal starting from its colonization of the continental water body.

Sex was assessed macroscopically whenever possible, otherwise by histological examination of gonad tissue. In this case, a portion of gonadal tissue was fixed in $4 \%$ formalin in phosphate buffer $\mathrm{pH}$ 7.2. The sample was then dehydrated by washing in ethyl alcohol at increasing concentrations $(70 \%, 80 \%, 90 \%$, 96\%) and included in resin Technovit 7100. The resin blocks were then cut at the microtome (Leiz 1512) to $3 \mu \mathrm{m}$ thickness, and sections were stained by immersion in Polichrome I/Polychrome II (Bennett et al. 1976) solutions of Methylene Blue and Azure II and basic fuchsin, respectively, for microscopic observation. The histological assessment was carried out following the guidelines of Colombo and Grandi (1996).

\subsection{Chemical analysis of eels}

A subsample (around $0.5 \mathrm{~g}$ ) of freeze-dried dorsal muscle of each eel was homogenized and extracted with $50 \mathrm{~mL}$ of a acetone $/ n$-hexane (pesticide grade, Carlo Erba, Italy; $v / v$ ) mixture in glass microfibre thimbles $(19 \mathrm{~mm}$ internal diameter $\times 90 \mathrm{~mm}$ external length, Whatman, England) using a modified Soxhlet apparatus (Velp Scientifica, ECO 6 thermoreactor). The gravimetric determination of lipids was performed after solvent evaporation. Lipids were then suspended in $2 \mathrm{~mL}$ of $n$-hexane and destroyed with $5 \mathrm{~mL}$ of $\mathrm{H}_{2} \mathrm{SO}_{4}(98 \%$, Carlo Erba, Italy). Chlorinated compounds were then recovered by several $n$-hexane washings. Hexane extracts were concentrated and cleaned-up on a Florisil column $(4 \times 0.7 \mathrm{~cm})$ according to a procedure used in an intercalibration exercise (Galassi et al. 1981). The purified extracts $(1 \mu \mathrm{L})$ of each sample were then introduced by on-column injection into a gas chromatograph (Carlo Erba TOP8000) equipped with a capillary column (WCOT fused silica CP-Sil 8CB, Varian USA, $50 \mathrm{~m} \times$ $0.25 \mathrm{~mm}$, film thickness $0.25 \mu \mathrm{m}$ ) and an electron capture detector (Carlo Erba ECD 80 ThermoQuest Italia), heated at $320^{\circ} \mathrm{C}$. The temperature programme was from $60^{\circ} \mathrm{C}$ to $180^{\circ} \mathrm{C}$ at $20^{\circ} \mathrm{C} / \mathrm{min}$, followed by a run from $180^{\circ} \mathrm{C}$ to $200^{\circ} \mathrm{C}$ at $1.5^{\circ} \mathrm{C} / \mathrm{min}$, a further run from $200^{\circ} \mathrm{C}$ to $270^{\circ} \mathrm{C}$ at $3^{\circ} \mathrm{C} / \mathrm{min}$ and a final isotherma at $270^{\circ} \mathrm{C}$ for $20 \mathrm{~min}$, with helium as the carrier gas $(1 \mathrm{~mL} / \mathrm{min})$ and nitrogen as the auxiliary gas $(30 \mathrm{~mL} / \mathrm{min})$.

For the GC-ECD analysis, an external standard mixture of pp'DDT, pp'DDD, pp'DDE, HCB, $\alpha$ - and $\gamma-\mathrm{HCH}$ was prepared by dissolving $10 \mathrm{mg}$ of pure compounds (Pestanal, Sigma-Aldrich, Germany) in iso-octane and diluting the solution to a final 
concentration of $10 \mu \mathrm{g} / \mathrm{L}$. Aroclor 1260 (Alltech, IL, USA) with the addition of PCB 28, PCB 52 and PCB 118 , was used for PCBs quantification. The sum of the analysed PCBs corresponded to about the $97 \%$ in weight of the reference standard. The sum of PCB 28, PCB 52, PCB 101, PCB 118, PCB 138, PCB 153 and PCB 180, which are the most frequently determined, is reported as "target PCBs". Good laboratory practices were tested on the standard reference materials Community Bureau of Reference (BCR)-598 and BCR-349 (Community Bureau of Reference, Brussels) for pesticide and PCB residues, respectively, analysing samples in triplicate. The percentages of recovery were $107.5 \% \pm 4 \%$ (pp'DDE), $106.2 \% \pm 4 \%$ (pp'DDD), $106.2 \% \pm 3 \%$ (pp'DDT), 105.2\% ${ }^{\prime} 9.9 \%$ (HCB), $107.7 \% \pm 7.2 \%(\alpha-$ $\mathrm{HCH})$ and $89.5 \% \pm 9.1 \%(\gamma-\mathrm{HCH})$, while those for PCBs were between $91.3 \% \pm 1.1 \%$ and $102.2 \% \pm 1.6 \%$. The detection limit for single organochlorine pesticide and PCB homologues was $0.1-0.5 \mathrm{ng} / \mathrm{g}$ lipid weight (lw), depending on the compounds.

\subsection{Statistical analysis of data}

Data are reported as median and mean values with standard deviation. Comparisons between bio- and morphometrical data of eels (Table 1) were performed by ANOVA followed by the post-hoc Scheffé test. Comparisons between contaminants in eels of Lesina Lagoon sampled in October and December and between Tevere and Lesina specimens were carried out using the Student's $t$ test for independent samples, with significance level $\mathrm{p}$ set at 0.05 . Finally, the relationship between lipid content and POPs was analysed using the Pearson's correlation test detecting the appropriate equation trend.

\section{Results and discussion}

\subsection{Intra-population and inter-population variability} of POPs

Bio- and morphometrical data of the sampled eels are reported in Table 1. No significant differences in length, weight and age were found between the eels collected at different times in the same site. Therefore, considering the eels as three batches, corresponding to the three different sampling sites, the age resulted homogeneous and it was found that Lesina eels were significantly bigger than those of Caprolace ( $p<0.001$ both for length and weight) and Tevere ( $p=0.003$ for length and $p=0.021$ for weight). The observed size differences could be justified by the different environmental conditions; in general eels growth faster in brackish water than in freshwater (Melià et al. 2006) but the very high salinity of Caprolace Lake may determine growth inhibition (Capoccioni et al. 2009).

The number of male and female eels collected at Caprolace was 6 and 10, respectively (plus 6 more eels that were sexually undifferentiated); it was 0 and 10 at Lesina and 7 and 1 at Tevere River. The predominance of silver eels in Tevere River may be related with the sex of these specimens, since males become silver before females (Melià et al. 2006).

As concern Caprolace eels a significant lower lipid content than the one of Lesina $(p<0.001)$ and of Tevere $(p<0.001)$ was observed, probably for the sampling period when the water temperature reaches the minimum value of the year (around $7^{\circ} \mathrm{C}$, Signorini et al. 2009).

In general, when POP concentrations are expressed on a lipid basis, intra-population variability in fish is usually explained by differences in size and age (Schindler et al. 1995; Harding et al. 1997; Volta et al. 2009), which can be used as co-variates in the statistical analysis when geographical differences are examined. Concentrations are usually expected to increase with age and size: for instance, a study of eels by Ferrante et al. (2010) found a positive correlation between total PCB and DDT concentrations and body length. On the contrary, in the present investigation, no correlation between contaminants and body length were observed for Tevere eels (for PCBs: $p=0.314$; for DDTs: $p=0.829$ ), (while for Lesina Lagoon a significant negative correlation was found between DDTs and body length for eels caught in December $\left(R^{2}=0.68, p=0.042\right)$. No significant correlation was found either between contamination levels and age (Tevere $\rightarrow$ PCBs: $p=0.615$; DDTs: $p=$ 0.909 ; Lesina $\rightarrow$ PCBs: $p=0.099$; DDTs: $p=0.244$, in the case of pp'DDT $p=0.064$ ).

The intra-population variability was extremely high for POPs and for lipid percentages at Caprolace Lake, where some eels were probably starving in that period of the year. Even after normalizing the concentrations of contaminants on lipids, the variability remained very high and an inverse non linear relation was found between POPs and lipid percentages of eels (Fig. 2). In starving fish the neutral 
Table 1 Bio- and morphometrical data (lipid content, length, weight, stage, age and sex) of eels collected in 2007-2008

\begin{tabular}{|c|c|c|c|c|c|c|c|}
\hline Site & Month & Lipids (\%) & Total length $(\mathrm{cm})$ & Total weight (g) & Stage & Age (year) & Sex \\
\hline \multirow[t]{22}{*}{ Caprolace Lake } & \multirow[t]{16}{*}{ February } & 6.2 & 18.5 & 8.5 & $\mathrm{Y}$ & 5 & Und \\
\hline & & 0.1 & 23.5 & 16.1 & $\mathrm{Y}$ & 4 & Und \\
\hline & & 0.5 & 26.5 & 22.5 & $\mathrm{Y}$ & 9 & Und \\
\hline & & 2.5 & 27.0 & 28.6 & $\mathrm{Y}$ & 6 & Und \\
\hline & & 11.6 & 30.0 & 37.0 & $\mathrm{Y}$ & 7 & Und \\
\hline & & 0.3 & 35.0 & 45.6 & $\mathrm{Y}$ & 8 & $\mathrm{~F}$ \\
\hline & & 17.5 & 35.0 & 69.0 & $\mathrm{Y} / \mathrm{S}$ & 8 & M \\
\hline & & 12.5 & 36.0 & 72.38 & $\mathrm{Y} / \mathrm{S}$ & 6 & M \\
\hline & & 0.6 & 36.0 & 60.8 & $\mathrm{Y}$ & 8 & $\mathrm{~F}$ \\
\hline & & 16.6 & 38.0 & 81.3 & $\mathrm{Y} / \mathrm{S}$ & 5 & $\mathrm{M}$ \\
\hline & & 0.8 & 43.5 & 109.0 & $\mathrm{~S}$ & 7 & $\mathrm{~F}$ \\
\hline & & 14.9 & 44.0 & 161.4 & $\mathrm{Y} / \mathrm{S}$ & 9 & $\mathrm{~F}$ \\
\hline & & 3.6 & 53.0 & 245.3 & $\mathrm{Y}$ & 7 & $\mathrm{~F}$ \\
\hline & & 2.0 & 56.6 & 262.9 & $\mathrm{~S}$ & 8 & $\mathrm{~F}$ \\
\hline & & 12.2 & 60.0 & 293.3 & $\mathrm{Y} / \mathrm{S}$ & 11 & $\mathrm{~F}$ \\
\hline & & 16.0 & 60.0 & 360.3 & $\mathrm{Y} / \mathrm{S}$ & 10 & $\mathrm{~F}$ \\
\hline & \multirow[t]{6}{*}{ March } & 11.4 & 27.5 & 31.4 & $\mathrm{Y}$ & 6 & Und \\
\hline & & 5.3 & 29.8 & 44.3 & $\mathrm{Y}$ & 5 & $\mathrm{M}$ \\
\hline & & 11.5 & 35.4 & 78.4 & $\mathrm{Y}$ & 7 & M \\
\hline & & 16.3 & 36.0 & 65.4 & $\mathrm{Y}$ & 6 & M \\
\hline & & 0.5 & 40.5 & 91.0 & $\mathrm{Y}$ & 5 & $\mathrm{~F}$ \\
\hline & & 0.5 & 44.3 & 94.7 & $\mathrm{Y}$ & 10 & $\mathrm{~F}$ \\
\hline \multirow[t]{10}{*}{ Lesina Lagoon } & \multirow[t]{4}{*}{ October } & 14.8 & 52.8 & 231.6 & $\mathrm{Y}$ & 5 & $\mathrm{~F}$ \\
\hline & & 24.2 & 56.0 & 370.7 & $\mathrm{~S}$ & 8 & $\mathrm{~F}$ \\
\hline & & 23.7 & 59.0 & 336.8 & $\mathrm{~S}$ & 5 & $\mathrm{~F}$ \\
\hline & & 13.6 & 64.0 & 510.4 & Y & 5 & $\mathrm{~F}$ \\
\hline & \multirow[t]{6}{*}{ December } & 14.9 & 42.0 & 89.0 & $\mathrm{Y}$ & 5 & $\mathrm{~F}$ \\
\hline & & 10.1 & 44.0 & 112.1 & $\mathrm{Y}$ & 5 & $\mathrm{~F}$ \\
\hline & & 14.5 & 63.5 & 446.4 & $\mathrm{Y} / \mathrm{S}$ & 8 & $\mathrm{~F}$ \\
\hline & & 19.8 & 64.0 & 422.2 & $\mathrm{Y}$ & 6 & $\mathrm{~F}$ \\
\hline & & 24.5 & 70.5 & 762.0 & $\mathrm{~S}$ & 6 & $\mathrm{~F}$ \\
\hline & & 20.8 & 72.5 & 711.2 & $\mathrm{~S}$ & 7 & $\mathrm{~F}$ \\
\hline \multirow[t]{8}{*}{ Tevere River } & \multirow[t]{8}{*}{ November } & 17.3 & 38.5 & 92.6 & $\mathrm{Y} / \mathrm{S}$ & 6 & $\mathrm{M}$ \\
\hline & & 18.3 & 39.0 & 95.0 & $\mathrm{Y} / \mathrm{S}$ & 7 & M \\
\hline & & 16.0 & 41.0 & 107.4 & $\mathrm{~S}$ & 6 & $\mathrm{M}$ \\
\hline & & 23.4 & 42.0 & 156.2 & $\mathrm{~S}$ & 6 & $\mathrm{M}$ \\
\hline & & 26.4 & 44.0 & 144.8 & $\mathrm{~S}$ & 9 & $\mathrm{M}$ \\
\hline & & 24.2 & 46.5 & 162.5 & $\mathrm{~S}$ & 5 & $\mathrm{M}$ \\
\hline & & 25.7 & 48.5 & 181.2 & $\mathrm{~S}$ & 9 & $\mathrm{M}$ \\
\hline & & 15.7 & 56.0 & 312.2 & $\mathrm{~S}$ & 7 & $\mathrm{~F}$ \\
\hline
\end{tabular}

$Y$ yellow eel, $S$ silver eel, $Y / S$ intermediate stage between $\mathrm{Y}$ and $\mathrm{S}, U$ Und undifferentiated, $M$ male, $F$ female 
Fig. 2 Relation between lipid percentages $(\%)$ and POPs concentrations (ng/g lw) measured in eels collected at Caprolace Lake

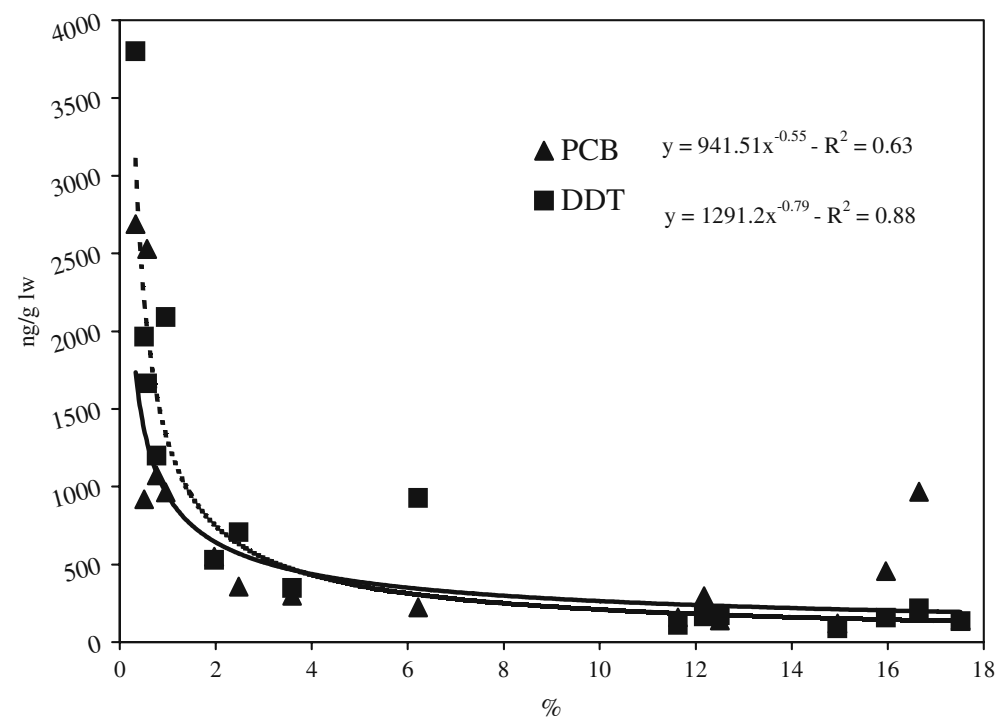

muscle lipids are reduced faster than the polar ones (Osako et al. 2003). Since it has been observed that the polar complex lipids recovery from tissues becomes difficult when simple lipids content decreases (Christie 1993), total lipid can be underestimated in starving fish.

No significant differences in POPs contamination were found between the two sampling campaigns at Lesina (PCBs: $t=1.61, p=0.15$; DDTs: $t=2.03, p=$ $0.077)$ and, as a consequence, these data are considered as one batch. Due to the extremely high intrapopulation variability found in the Caprolace samples, inter-population comparisons could be carried out only between eels collected in Tevere River and those collected in Lesina Lagoon. The average concentrations of PCBs in Lesina Lagoon $(42.4 \pm 11.8 \mathrm{ng} / \mathrm{g} \mathrm{lw})$ were two orders of magnitude lower than those measured in Tevere eels $(1,111.9 \pm 436.4 \mathrm{ng} / \mathrm{g} \mathrm{lw})(t=$ $7.81, p<0.01$, Table 2 ). The heavily urbanized watershed of Tevere River, which also receives the contributions of the heavy polluted Aniene River, likely contains PCBs point pollution sources, whereas Lesina Lagoon, which lies in a national park, is probably affected only by long-range transport. Even if PCBs are no longer produced and used in Italy, they are still contained in many industrial applications and household materials, such as capacitors and transformers, and they can reach surface waters in industrialized and urbanized areas mainly from leachates of waste landfills and fall-out from incinerators (van Gerven et al. 2004). Furthermore, these pollutants may appear during flood events from the re-suspension of sediment contaminated long ago, and they are also present in treatment plant discharges and the run-off waters of solid waste landfills (Slack et al. 2005).

The relative contribute of the seven representative chosen "target PCBs" (Table 2) to the total PCBs, on the average was $74.0 \% \pm 4.7 \%$ at Caprolace Lake, $61.4 \% \pm 5.0 \%$ at Lesina Lagoon and $61.6 \% \pm 6.4 \%$ at Tevere River. These percentages are similar to those reported in the literature for other European environments (Mariottini et al. 2006), confirming their importance as indicators of PCB pollution.

The differences were less pronounced for DDT homologues; only the parent compound pp'DDT $(59.8 \pm 25.3 \mathrm{ng} / \mathrm{g} \mathrm{lw})$ and pp'DDD $(98.0 \pm 30.2 \mathrm{ng} / \mathrm{g}$ $\mathrm{lw})$ were significantly higher $(\mathrm{t}=3.88 p<0.01, \mathrm{t}=4.58$ $p<0.01$, respectively) in Tevere eels than in those collected at Lesina (average pp'DDT: $25.2 \pm 11.2 \mathrm{ng} / \mathrm{g}$ lw, average pp'DDD: $41.9 \pm 21.8 \mathrm{ng} / \mathrm{g} \mathrm{lw}$ ).

Although long-range transport should be the main pollution source for both sites since the agricultural use of this insecticide in Italy was stopped in 1978, recent DDT input seems to influence the DDT homologue composition of Tevere eels. In fact, the ratio between the parent compound, pp'DDT, and the most stable metabolite, pp'DDE, was higher in Tevere River than at Lesina in both sampling periods.

Although differences of contamination between the eel samples collected in the two ecosystems might be partially due to the sex ratio of eels, being almost all males in Tevere River and all female in Lesina 
Table 2 Number $(n)$, median, mean $( \pm \mathrm{SD})$ of biometrical data, of lipid percentage, and of POPs levels (ng/glw) of eels collected in 2007-2008

\begin{tabular}{|c|c|c|c|c|c|c|c|c|c|c|}
\hline & \multicolumn{8}{|c|}{ Shallow brackish waters } & \multirow{2}{*}{\multicolumn{2}{|c|}{$\begin{array}{l}\text { Riverine waters } \\
\text { Tevere River }\end{array}$}} \\
\hline & \multicolumn{4}{|c|}{ Caprolace Lake } & \multicolumn{4}{|c|}{ Lesina Lagoon } & & \\
\hline & \multicolumn{2}{|c|}{ February $2008(n=16)$} & \multicolumn{2}{|c|}{ March $2008(n=6)$} & \multicolumn{2}{|c|}{ October $2007(n=4)$} & \multicolumn{2}{|c|}{ December $2007(n=6)$} & \multicolumn{2}{|c|}{ November $2007(n=8)$} \\
\hline & Median & Mean \pm SD & Median & Mean \pm SD & Median & Mean \pm SD & Median & Mean \pm SD & Median & Mean \pm SD \\
\hline Length (cm) & 36.0 & $38.9 \pm 13.0$ & 35.7 & $35.6 \pm 6.3$ & 57.5 & $58.0 \pm 4.8$ & 63.8 & $59.4 \pm 13.2$ & 43.0 & $44.4 \pm 5.8$ \\
\hline Weight (g) & 70.7 & $117.1 \pm 112.2$ & 71.9 & $67.5 \pm 25.5$ & 353.8 & $362.4 \pm 115.1$ & 434.3 & $423.8 \pm 285.2$ & 150.5 & $156.5 \pm 71.0$ \\
\hline Age & 7.5 & $7.4 \pm 1.9$ & 6.0 & $6.5 \pm 1.9$ & 5.0 & $5.8 \pm 1.5$ & 6.0 & $6.2 \pm 1.2$ & 6.5 & $6.9 \pm 1.5$ \\
\hline$\%$ Lipids & 4.9 & $7.4 \pm 6.8$ & 8.4 & $7.6 \pm 6.5$ & 19.3 & $19.1 \pm 5.7$ & 17.4 & $17.4 \pm 5.2$ & 20.9 & $20.9 \pm 4.5$ \\
\hline PCBs & 406.6 & $742.6 \pm 800.1$ & 250.2 & $648.7 \pm 748.4$ & 46.2 & $49.2 \pm 10.4$ & 35.8 & $37.9 \pm 11.3$ & $1,221.9$ & $1,111.9 \pm 436.4$ \\
\hline Target PCBs & 307.7 & $555.7 \pm 608.9$ & 178.1 & $503.7 \pm 606.8$ & 27.4 & $28.7 \pm 6.6$ & 22.6 & $24.2 \pm 7.8$ & 796.3 & $685.3 \pm 258.6$ \\
\hline $\mathrm{HCB}$ & 3.3 & $4.4 \pm 2.3$ & 3.2 & $4.8 \pm 2.9$ & 6.9 & $7.2 \pm 1.2$ & 6.0 & $5.9 \pm 1.2$ & 27.0 & $26.1 \pm 7.2$ \\
\hline$\alpha-\mathrm{HCH}$ & 2.0 & $3.9 \pm 3.7$ & 1.3 & $3.9 \pm 4.1$ & 1.5 & $1.7 \pm 0.7$ & 1.6 & $1.5 \pm 0.2$ & 2.7 & $2.9 \pm 1.0$ \\
\hline$\gamma-\mathrm{HCH}$ & 1.4 & $2.0 \pm 2.8$ & 0.7 & $1.8 \pm 1.9$ & 0.2 & $0.2 \pm 0.0$ & 1.0 & $1.0 \pm 0.2$ & 1.1 & $1.1 \pm 0.3$ \\
\hline pp'DDE & 353.5 & $786.0 \pm 912.0$ & 209.0 & $634.5 \pm 732.7$ & 571.2 & $686.4 \pm 363.7$ & 324.8 & $348.5 \pm 139.5$ & 309.2 & $320.9 \pm 71.6$ \\
\hline pp'DDD & 38.9 & $60.0 \pm 81.8$ & 19.9 & $40.7 \pm 40.7$ & 48.7 & $53.0 \pm 21.3$ & 32.2 & $34.5 \pm 20.5$ & 98.6 & $98.0 \pm 30.2$ \\
\hline pp'DDT & 24.8 & $46.2 \pm 49.0$ & 12.9 & $24.8 \pm 23.6$ & 25.8 & $29.2 \pm 11.9$ & 20.8 & $22.6 \pm 11.1$ & 52.3 & $59.8 \pm 25.3$ \\
\hline DDTs & 438.2 & $892.2 \pm 1035.4$ & 239.9 & $699.9 \pm 796.4$ & 645.8 & $768.6 \pm 396.3$ & 380.0 & $405.6 \pm 170.5$ & 468.3 & $478.7 \pm 119.4$ \\
\hline
\end{tabular}

Lagoon (Table 1), the ratio between total PCBs and total DDTs at each sampling site should be independent from the sample composition; this ratio is 2.32 for Tevere River and 0.07 for Lesina Lagoon, confirming the dominance of industrial/urban pollution sources on the agricultural ones.

Pollution by lindane $(\gamma-\mathrm{HCH})$ and its $\alpha$-isomer was very low (Table 2), as expected for this insecticide since it has a very restricted use in Italy and a low tendency to bioaccumulate in animal tissues.

HCB was used as fungicide in the past and some residues may derive from past agricultural use; however, according to Pacyna et al. (2003), more recent sources should be industrial productions, waste treatments, as well as disposal and application of contaminated pesticides in agriculture. Actually, the concentrations of this pollutant were significantly higher in Tevere River $(26.1 \pm 7.2 \mathrm{ng} / \mathrm{g} \mathrm{lw}, t=8.48 p<$ $0.01)$ than in the coastal lagoon $(6.4 \pm 1.3 \mathrm{ng} / \mathrm{g} \mathrm{lw})$ as in the case of PCBs.

\subsection{Biomonitoring using the eel}

Since the European eel is a semi-littoral benthic species, it reflects the variability of this environment which can trap and store persistent hydrophobic chemicals entering the water body from point pollution sources. Consequently, part of eel variability in POP bioaccumulation observed in the present study could be ascribed to small-scale habitat variability within the water body. A significant patchiness of POP pollution in the benthic coastal environment was already observed (Chan and Caley 2003; Galassi et al. 2008; Bettinetti et al. 2009) as well as the existence of microhabitats which influence both the occurrence of different potential prey species and the different sediment contamination levels.

Therefore, a small sample consisting of few eels is hardly representative of the eel population in a site, that is characterized by remarkable variations in space and time of age, size and sex, depending on eel movements and migrations, and on differential habitat preferences at the different life stages, even within the continental phase (Daverat et al. 2005; Daverat and Tomás 2006).

Behavioural features of this species may also influence the capture of specimens: eels may behave quite differently according to size, stage of maturation, food preference, tide, season, moon, rain and/or depth, and a sample cannot represent the stock of the whole population (FAO 1980). 
Moreover, since the eel is a very opportunistic species in terms of diet, pollutant intake through food is probably the most unpredictable variable, as it depends on the micro-habitat where this sedentary species spends most of its life before leaving for migration to the sea. Furthermore, the annual growth rate of eel can be quite variable from site to site due to differences in water temperature, salinity, food availability and densitydependent competition (De Leo and Gatto 1996). As body growth may cause a dilution of the POPs and the fast lipid consumption during the starvation might concentrate them in the remaining fats, physiological conditions should be also considered when choosing the size and the sampling period of eels.

For all these drawbacks POPs levels can be extremely variable between individuals even within the same water body; therefore, we doubt that the analysis of few eel specimen may be representative of a whole water body. On the other side, the only realistic alternative to eel as the unique species for the biomonitoring of European aquatic ecosystems would be to select fish species that can be considered as ecological equivalents. In fact, as different POPs bioaccumulation pathways have been found in littoral, deep benthic and pelagic organisms (Holmqvist et al. 2005; Kidd et al. 2001), representative species of these different habitats should be considered for an evaluation of POPs pollution in deep lakes. For instance, Noble et al. (2007) proposed to classify fish species into ecological guilds to identify those that could be used for biomonitoring purposes. This approach is very powerful as it could bypass the need for a unique fish species as a bioindicator, providing comparable results and enabling the coverage of all geographical areas in European freshwaters.

Our results indicate that the eel could be still suitable for biomonitoring the ecological quality of coastal brackish and riverine waters, since they are tolerant of a wide range of salinity and are easily caught in suitable numbers. However, when eels are adopted as a sentinel organism, attention should be paid to the physiological condition of fish. For this reason, data referring to Caprolace eels were not considered for any comparison with the other two aquatic environments examined in this study, as already mentioned, or for any comparison with literature data (Table 3). The most recent investigations (of the last 5 years) which report POPs contamination expressed on lipid content for coastal and estuarine Italian environments confirm that both PCBs and HCB contaminations are generally higher in rivers than in coastal lagoons which are all located in protected areas. Among DDT homologues, pp'DDE is the main residue found in the muscle of eels; however, the parent compound pp'DDT is still present, probably coming from secondary sources, since its use was banned in 1978 in Italy and its production officially ceased in 1996 (Bettinetti et al. 2008). The comparison among contamination of the different environments shows that levels of HCB, DDTs and PCBs in rivers is comparable, while the Lesina Lagoon seems to be the most contaminated site among lakes for pp'DDE and HCB, but not for PCBs.

Table 3 POP concentrations (mean $\pm \mathrm{SD}$; expressed as $\mathrm{ng} / \mathrm{g} \mathrm{lw}$ ) in the muscle of Anguilla anguilla caught in different coastal lagoons and rivers from different sites in Italy

\begin{tabular}{lllllll}
\hline Location & HCB & pp'DDD & pp'DDE & pp'DDT & PCBs & Reference \\
\hline $\begin{array}{l}\text { Santa Giusta Lagoon } \\
\text { Orbetello Lagoon }\end{array}$ & NA & NA & NA & NA & $\begin{array}{l}67.2 \pm 46.7 \\
162.1 \pm 23.3\end{array}$ & Mariottini et al. 2006 \\
Orbetello Lagoon & & & & & & Focardi et al. 2009 \\
S & $<0.6-2.9$ & & $16.5-94.6$ & & $92.4-191.3$ & \\
W & $<0.6-1.7$ & & $18.1-89.5$ & & $101.3-236.2$ & Present study \\
Lesina Lagoon & $6.6 \pm 1.2$ & $43.8 \pm 20.9$ & $517.4 \pm 251.6$ & $25.9 \pm 11.4$ & $43.6 \pm 10.8$ & Ferrante et al. 2010 \\
Garigliano River & $11.0 \pm 14.7$ & $62.2 \pm 92.7$ & $112.8 \pm 107.3$ & $58.2 \pm 39.5$ & $898.9 \pm 626.8$ & Present study \\
Tevere River & $26.1 \pm 7.2$ & $98.0 \pm 30.2$ & $320.9 \pm 71.6$ & $59.8 \pm 25.3$ & $1,111.9 \pm 436.4$ & \\
\hline
\end{tabular}

Reported studies are those carried out in the last decade

$N A$ not available, $S$ summer, $W$ winter

${ }^{a}$ Min-max at different sampling points 


\section{Conclusions}

Within the WFD, fishes are one of the Biological Quality Elements (BQEs) used to assess the ecological status of aquatic ecosystems. While the European eel is suitable for monitoring bioaccumulative pollutants in coastal lagoons, shallow lakes and rivers, other fish species, possibly pelagic ones, should be adopted as representative organisms for deep lakes. Apart from these limitations, this species is very important both from an ecological and commercial point of view, and knowledge concerning levels of old and emerging pollutants in its tissues should be improved in order to estimate the impact of xenobiotics on the decline of this species.

Acknowledgments This work was supported by the Italian Ministry of University and Scientific Research-PRIN Project 2006: "An Integrated Approach to the Conservation and Management of the European Eel in the Mediterranean Region".

\section{References}

Barron, M. G., Nardo, C., \& Yurk, J. J. (1996). Bioavailability of PCBs in channel catfish exposed to a treated municipal effluent. Environmental Technology, 17(5), 557-560.

Belpaire, C., \& Goemans, G. (2007). The European eel Anguilla anguilla, a rapporteur of the chemical status for the water framework directive? Vie et Milieu-Life and Environment, 57(4), 235-252.

Bennett, H. S., Wyrick, A. D., LeeJohn, S. W., \& McNeil, H. (1976). Preparing tissues embedded in plastic for light microscopy, with special reference to glycol methacrylate, glass knives and simple stains. Biotechnic \& Histochemistry, 51, 71-97.

Bettinetti, R., Quadroni, S., Galassi, S., Bacchetta, R., Bonari, L., \& Vailati, G. (2008). Is meltwater from Alpine glaciers a secondary DDT source for lakes? Chemosphere, 73, 1027-1031.

Bettinetti, R., Galassi, S., Falandysz, J., Camusso, M., \& Vignati, D. (2009). Sediment quality assessment in the Gulf of Gdańsk (Baltic Sea) using complementary lines of evidence. Environmental Management, 43, 13131320.

Bettinetti, R., Galassi, S., Guzzella, L., Quadroni, S., \& Volta, P. (2010). The role of zooplankton in DDT biomagnification in a pelagic food web of Lake Maggiore (Northern Italy). Environmental Science and Pollution Research. doi:10.1007/s11356-010-0337-8.

Buet, A., Banas, D., Vollaire, Y., Coulet, E., \& Roche, H. (2006). Biomarker responses in European eel (Anguilla anguilla) exposed to persistent organic pollutants. A field study in the Vaccarès lagoon (Camargue, France). Chemosphere, 65(10), 1846-1858.
Capoccioni, F., Bevacqua, D., Melià, P., De Leo, G. A., \& Ciccotti, E. (2009). Characterization of the vital features in three Italian eel populations (Anguilla anguilla). XIX Congresso Nazionale della Società Italiana di Ecologia, 15-18 September 2009, Bolzano, Italy.

Chan, B. K. K., \& Caley, K. J. (2003). Hong Kong field guides 4: Sandy shores. Hong Kong: Wanli Book Co.

Christie, W. W. (1993). Preparation of lipid extracts from tissues. In W. W. Chirstie (Ed.), Advances in lipid methodology - two (pp. 195-213). Dundee: Oily Press.

Colombo, G., \& Grandi, G. (1996). Histological study of the development and sex differentiation of the gonad in the European eel. Journal of Fish Biology, 48, 493-512.

Dachs, J., Eisenreich, S. J., \& Hoff, R. M. (2000). Influence of eutrophication on air-water exchange, vertical fluxes and phytoplankton concentration of persistent organic pollutants. Environmental Science \& Technology, 34, 10951102.

Daverat, F., \& Tomás, J. (2006). Tactics and demographic attributes in the European eel Anguilla anguilla in the Gironde watershed, SW France. Marine Ecology Progress Series, 307, 247-257.

Daverat, F., Tomas, J., Lahaye, M., Palmer, M., \& Elie, P. (2005). Tracking continental habitat shifts of eels using otolith $\mathrm{Sr} / \mathrm{Ca}$ ratios: validation and application to the coastal, estuarine and riverine eels of the GirondeGaronne-Dordogne watershed. Marine and Freshwater Research, 56(5), 619-627.

de Kock, W. C., \& Bowmer, C. T. (1993). Bioaccumulation, biological effects, and food chain transfer of contaminants in the zebra mussel (Dreissena polymorpha). In T. F. Nalepa \& D. W. Schloesser (Eds.), Zebra Mussels: Biology, impacts and control (pp. 503-533). Boca Raton: Lewis Publishers.

De Leo, G. A., \& Gatto, M. (1996). Trends in vital rates of the European eel: evidence for density dependence? Ecological Applications, 6(4), 1281-1294.

EPA. (1999). PCB update: impact on fish advisories. EPA-823F-99019.

EPA. (2000). Water quality standards. Establishment of numeric criteria for priority toxic pollutants for the state of California. Federal Register 65, number 97.

FAO. (1980). Guidelines for sampling fish in inland waters. EIFAC, Paper 33.

Ferrante, M. C., Clausi, M. T., Meli, R., Fusco, G., Naccari, C., \& Lucisano, A. (2010). Polychlorinated biphenyls and organochlorine pesticides in European eel (Anguilla anguilla) from the Garigliano River (Campania region, Italy). Chemosphere, 78, 709-716.

Focardi, S., Mariottini, M., Renzi, M., Perra, G., \& Focardi, S. (2009). Anthropogenic impacts on the Orbetello lagoon ecosystem. Toxicology and Industrial Health, 25, 365371.

Galassi, S., Gandolfi, G., \& Pacchetti, G. (1981). Chlorinated hydrocarbons in fish from the River Po (Italy). The Science of the Total Environment, 20, 231-240.

Galassi, S., Bettinetti, R., Neri, M. C., Jeannot, R., Dagnac, T., Bristeau, S., et al. (2008). A multispecies approach for monitoring persistent toxic substances in the Gulf of Gdansk (Baltic Sea). Ecotoxicology and Environmental Safety, 69, 39-48. 
Griffiths, D. (2006). Pattern and process in the ecological biogeography of European freshwater fish. The Journal of Animal Ecology, 75(3), 734-751.

Harding, G. C., LeBlanc, R. J., Vass, W. P., Addison, R. F., Hargrave, B. T., Pearre, S., Jr., et al. (1997). Bioaccumulation of polychlorinated biphenyls (PCBs) in the marine pelagic food web, based on a seasonal study in the southern Gulf of St. Lawrence, 1976-1977. Marine Chemistry, 56, 145-179.

Holmqvist, N., Stenroth, P., Berglund, O., Nyström, P., Graneli, W., \& Larsson, P. (2005). Lake trophic status and bioaccumulation of polychlorinated biphenyls in benthic organisms: a comparison between littoral and profundal invertebrates. Canadian Journal of Fisheries and Aquatic Sciences, 62(6), 1201-1209.

ICES. (2009). Workshop on the age reading of European and American eel (WKAREA), 20-24 April, Bordeaux, France. ICES CM 2009\ACOM: 48. pp. 66

Kidd, A., Bootsma, H. A., Hesslein, R. H., Muir, D. C. G., \& Hecky, R. E. (2001). Biomagnification of DDT through the benthic and pelagic food webs of Lake Malawi, East Africa: importance of trophic level and carbon source. Environmental Science \& Technology, 35, 14-20.

Koponen, K., Myers, M. S., Ritola, O., Huuskonen, S. E., \& Lindström-Seppä, P. (2001). Histopathology of feral fish from a PCB-contaminated freshwater lake. Ambio, 30(3), $122-126$.

Mariottini, M., Corsi, I., \& Focardi, S. (2006). PCB levels in European eel (Anguilla anguilla) from two coastal lagoons of the Mediterranean. Environmental Monitoring and Assessment, 117, 519-528.

Melià, P., Bevacqua, D., Crivelli, A. J., De Leo, G. A., Panfili, J., \& Gatto, M. (2006). Age and growth of the European eel Anguilla anguilla in the Camargue lagoons. Journal of Fish Biology, 68, 876-890.

Nielsen, T., \& Prouzet, P. (2008). Capture-based aquaculture of the wild European eel (Anguilla anguilla). In A. Lovatelli \& P. F. Holthus (Eds.), Capture-based aquaculture. Global overview. FAO Fisheries Technical Paper. No. 508 (pp. 141168). Rome: FAO.

Noble, R. A. A., Cowx, I. G., Goffaux, D., \& Kestemont, P. (2007). Assessing the health of European rivers using functional ecological guilds of fish communities: standardising species classification and approaches to metric selection. Fisheries Management \& Ecology, 14(6), 381392.

Osako, K., Kuwahara, K., Saito, H., Hossain, M. A., \& Nozaki, Y. (2003). Effect of starvation on lipid metabolism and stability of DHA content of lipids in horse mackerel (Trachurus japonicus) tissues. Lipids, 38(12), 1263-1267.

Pacyna, J. M., Brevik, K., Munch, J., \& Fudala, J. (2003). European atmospheric emission of selected persistent organic pollutants, 1970-1995. Atmospheric Environment, 37, 119-131.

Schindler, D. W., Kidd, K. A., Muir, D. C. G., \& Lockhart, W. L. (1995). The effects of ecosystem characteristics on contaminant distribution in northern freshwater lakes. The Science of the Total Environment, 160(161), 1-17.

Signorini, A., Migliore, G., Varrone, C., \& Izzo, G. (2009). The Lagoon of Caprolace. In E. Cecere, A. Petrocelli, G. Izzo, \& A. Sfriso (Eds.), Flora and vegetation of the Italian transitional water systems (pp. 147-158). Corila: LaguNet.

Slack, R. J., Gronow, J. R., \& Voulvouis, N. (2005). Household hazardous waste in municipal landfills: contaminants in leachate. The Science of the Total Environment, 337, 119137.

Söderström, M., Kerstin, N., Järnberg, U., Lithner, G., Rosén, G., \& Kylin, H. (2000). Seasonal variation of DDT compounds and PCB in a eutrophic and an oligotrophic lake in relation to algal biomass. Ambio, 29, 230-237.

van Gerven, T., Geysen, D., \& Vandecasteele, C. (2004). Estimation of the contribution of a municipal waste incinerator to the overall emission and human intake of PCBs in Welrijk, Flanders. Chemosphere, 54, 1303-1308.

van Ginneken, V., Palstra, A., Leonards, P., Nieveen, M., van den Berg, H., Flik, G., et al. (2009). PCBs and the energy cost of migration in the Europena eel (Anguilla anguilla L.). Aquatic Toxicology, 92, 213-220.

Volta, P., Tremolada, P., Neri, M. C., Giussani, G., \& Galassi, S. (2009). Age-dependent bioaccumulation of organochlorine compounds in fish and their selective biotransformation in top predators from Lake Maggiore (Italy). Water, Air, and Soil Pollution, 197, 193-209. 